\title{
No tomarás el nombre de Dios en vano. Blasfemia y castigo divino en Cataluña (siglos XVI-XVIII)*
}

\author{
Martí Gelabertó Vilagran
}

No tomarás el nombre de Dios en vano. Blasphemy and divine
punishment in Catalonia (XVI-XVIII centuries)

RESUMEN

Este estudio aborda la problemática de la historia del lenguaje en su faceta más trasgresora -las blasfemias-a través de los múltiples procesos de interacción social, política y religiosa entre cultura docta y cultura popular en el marco geográfico de la Cataluña del Antiguo Régimen. La reforma católica emprende un programa de disciplinamiento cultural contra las expresiones blasfemas fundamentado en la pedagogía del terror. Una estrategia aculturizadora que pone de manifiesto la lógica profunda de pensamiento mítico-supersticioso de la gente común ante acontecimientos de naturaleza sobrenatural.

\begin{abstract}
This study approcaches the history of the language problematics in his more violent - the blasphemies - across the multiple processes of social, political and religious interrelationship, between the elite culture and popular culture in the geographical frame of Catalonia in the XVI-XVIII centuries. The catholic reform undertakes an nature politics of combat against the blasphemous expressions inside his wide campaign of religious acculturation based on the terror pedagogy. An educational strategy that reveals the deep logic of mythical-superstitious thought of the common people before events of extraordinary nature.
\end{abstract}

Recibido: 19-11-2010 Aceptado: 15-01-2011

Este trabajo es fruto de una investigación más amplia beneficiaria de una beca Postdoctoral financiada por la Secretaria de Estado de Universidades e Investigación del Ministerio de Educación y Ciencia (EX2004-0257), realizada en la École des Hautes Etudes en Sciences Sociales de París (EHESS), Centre de Recherches Historiques, Groupe d'Etudes Hispaniques, dirigida por el profesor Bernard Vincent. 
Los mejores historiadores en la materia están de acuerdo en el hecho de que la inmensa mayoría de europeos de finales de la Edad Media y principios de la Edad Moderna blasfemaban constantemente ${ }^{1}$. La abundante documentación elaborada desde fines del Medioevo por las más elevadas instituciones laicas y religiosas de Europa demuestra la preocupación de las elites culturales del viejo continente por la gran extensión de los pecados de la lengua. Muchos documentos redactados en el transcurso de diversos siglos (edictos, procesos judiciales civiles y eclesiásticos, manuales de confesión, obras de casuistas...) son prueba fehaciente de la vitalidad y arraigo del vicio de blasfemar entre una ingente cantidad de personas, que abrazaba prácticamente todo el tejido social del Antiguo Régimen.

La blasfemia es tema de preocupación teológica entre los escritores moralistas de la Baja Edad Media. El franciscano Francesc Eiximenis (1340-1409) y el dominico Vicente Ferrer (1350-1419) censuran la extrema facilidad con que se jura y la común práctica de pronunciar blasfemias entre los cristianos de su época. Las autoridades católicas reconocían que mucha gente blasfemaba, aunque no todos tenían las mismas intenciones ni la misma malicia. El teólogo Enrique de Villalobos dice en su Manual de Confesores que para cada perjurio y blasfemia hay que tener en cuenta el propósito del que jura ${ }^{2}$. Generalmente eran consideradas exclamaciones o frases erróneas dichas frecuentemente en momentos de ofuscación mental en estados de cólera irascible causadas por las adversidades de la vida, provocadas por una excesiva ingestión de bebidas alcohólicas que alterasen emocionalmente a la persona más prudente o motivadas por los desbordamientos incontenibles de furor durante las partidas de juegos de naipes, inducidas por la ignorancia de la gente que las pronunciaba. Las blasfemias de carácter herético, con una explícita declaración contraria a la fe cristiana o que cuestionaran abiertamente un artículo del dogma católico, eran severamente castigadas por los tribunales correspondientes.

Etimológicamente, el término blasfemia procede del verbo griego blaptein (dañar, perjudicar) y del vocablo phène (palabra). Dentro de la teología cristiana, la blasfemia es la expresión injuriosa dirigida contra Dios, la Virgen María, los santos o las cosas sagradas en su relación de dependencia hacía el Creador. Según los cánones teológicos, pueden ser también expresiones blasfemas de tipo simple las maldiciones dirigidas contra las personas o animales con intención de ofender a la divinidad celestial. El lenguaje blasfematorio es comúnmente manifestado a través de la voz y del escrito, y en menor medida por medio de gestos ${ }^{3}$.

1 Acerca del tema de la historia de la blasfemia en Europa ver: CABANTOUS, A.: Histoire du blasphème en Occident, XVle-XIXe siècle, París, 1992; VV.AA.: Injures et blasphèmes, París, 1989; CHRISTIN, O.: "Sur le statut ambigu du blasphème au XVle siècle» en Ethnologie française, Paroles d'outrage, 1992, XXII, 2, pp. 337-343; DARTEVELLE, P. DENIS, Ph. RUBYN, J.: Blasphèmes et libertés, París-Bruselas, 1993; LEVELEUX, C.: La parole interdite, le problème dans la France medievales (XIIleXVle siècle): du péché au crime, París, 2001; CASAGRANDE, C.; VECCHIO, S.: Histoire des péchés capitaux au Moyen Âge, París, 2003; VISWNATHAN, G.: «Blasphemy and heresy, the modernist Challenger. A review article», Comparative study of society and history, 37-2, 1995, pp. 399-412.

2 VILLALOBOS, E. de.: Manual de confesores, Salamanca, 1625, p. 386.

3 FISHER, S.: «L'insulte: la parole et le geste», Langue française, 144, París, 2004, p. 53. 
No tomarás el nombre de Dios en vano. Blasfemia y castigo divino en Cataluña...

El catolicismo contrarreformista, si bien continua con la tradición escolática medieval de mantener una cierta indulgencia frente a juramentos y blasfemias expresadas por la gente común aturdida por el desorden moral o envalentonada por la embriaguez de los sentidos a causa de borracheras o cualquier otra tribulación personal, intensifica, no obstante, las censuras y la gravedad del pecado en los tratados de teología moral. El dominico Domingo de Soto (1494-1570), uno de los más destacados teólogos españoles del siglo XVI, pone énfasis en el carácter perverso de las blasfemias por contener palabras afrentosas y falsas dirigidas a Dios, ultraje peor que el robo y el homicidio ${ }^{4}$. El también dominico fray Luis de Granada (1494-1588) en su Guía de pecadores incide en la gravedad teológica de este pecado por las injurias indiscriminadas vertidas hacía la figura del Altísimo: «Entre los pecados mortales el primero y el más grave de todos es la blasfemia, que es un pecado muy vecino a los tres mayores pecados del mundo, que son infidelidad, desesperación y odios a Dios, que es absolutamente el mayor de todos ${ }^{5}$. Mucho más radical se muestra Lucas de Santo Tomás en su obra Excelencias del nombre de Jesús y su cofradía, contra juradores, blasfemos, y maldicientes, publicada en 1692:

«De los que mucho juran, y blasfeman, decimos, que tienen boca de escorpión, la cara la tienen de hombres, pero sus infernales lenguas son de escorpiones para hacer mal, andan por la tierra, y conversan con los hombres, más casi como las langostas, que destruyen los campos, yerbas, árboles, y quanto verde encontraban; así los blasfemos, todo lo asuelan, pues ni perdonan Santo, ni Santa, ni la Virgen, ni a su hijo, ni aún al mismo Dios. Las langostas envueltas en humo salieron del infierno, y las palabras de los blasfemos, envueltas en confusión, salen del mismo infierno (...) el diablo les mueve las lenguas sacrílegas, pues al mismo Dios se atreven, y como si fuera su igual le hazen guerra»6.

La distancia jerárquica entre Dios y los hombres no podía ser violada, las blasfemias, bien al contrario, introducían un factor de peligrosa familiaridad entre los cristianos y el Creador.

Sin embargo, y en contra de lo que pudiera suponerse, ni los tribunales reales ni la justicia eclesiástica en sus distintos brazos -inquisitorial y episcopal- tuvieron en su punto de mira prioritario la represión sangrienta del blasfemo. La severidad legislativa real en la que se incluían penas pecuniarias, azotes, enclavamiento de lengua y ejecución del reo no pasó de la letra impresa. Inquisidores y jueces diocesanos adoptaron la misma posición de condescendencia, salvo en los casos más graves de abierta rebeldía. A este respecto, Alain Cabantous señala que las disposiciones reales dirigidas contra los pecados de la lengua en Europa se enmarcan dentro de una estrategia global de actuación cuyo objetivo era con-

4 SOTO, D. de.: De iustitia et iure libri decem, 1556 (Colección clásicos políticos, Sección teólogos, juristas), Madrid, 1967, p. 267.

5 GRANADA, L. de.: Guía de pecadores, 1556, p. 469.

6 SANTO TOMAS, L. de.: Excelencias del nombre de Jesús, y su cofradía, contra juradores, blasfemos, y maldicentes, Madrid, 1697, p. 59. 
solidar la autoridad de unas monarquías absolutas todavía débiles en el plano político ${ }^{7}$.

En España, las principales leyes contra la blasfemia son legisladas no tanto para reafirmar el potencial autoritario del Estado absoluto como para resolver situaciones que requiriesen soluciones políticas en coyunturas especialmente delicadas para la religión católica. En la península, el período más activo en materia legislativa contra los blasfemos tuvo lugar en el transcurso de la primera mitad del siglo XVI, en los edictos de los años 1492, 1500, 1525 y 1566. Las pragmáticas publicadas durante el quinientos se encuadran en la defensa y afirmación del peso del catolicismo frente a las poblaciones conversas de judíos y musulmanes (edicto de 1492), mudéjares (edictos de 1500 y 1525), y calvinistas sublevados de los Países Bajos (edicto de 1566). Un plan diseñado estratégicamente para reforzar la unidad de la fe religiosa que aglutinara las diversas etnias y credos religiosos que hasta entonces habían convivido en España, una unidad confesional garantía de la cohesión territorial que supliera la falta de centralización política en que se vertebraba el país configurado en las Coronas de Castilla y de Aragón ${ }^{8}$. La justicia real española no persiguió a los blasfemos por motivos políticos, el Estado jamás consideró a los blasfemadores elementos peligrosos amenazadores de la cohesión social y política de la nación, circunstancia que si ocurría en Francia enfrentada a cruentas guerras de religión, y también en Inglaterra, tras el cisma de Enrique VIII con la Iglesia de Roma $^{9}$. La jerarquía política y religiosa española encauzará fundamentalmente su estrategia de lucha contra los blasfemos bajo criterios de reforma moral cuyo instrumento principal de combate será la propagación de la pedagogía del miedo.

Una de las principales preocupaciones del clero tridentino era advertir a los feligreses de la necesidad de renunciar a toda una serie de comportamientos muy extendidos dentro de la práctica cotidiana de la cultura popular, a los que la gente común se entregaba sin ninguna clase de pudor, como la creencia de que la simple fornicación no es pecado, ni el acto de masturbarse, ni acudir a los remedios mágicos del curandero urbano o rural para restablecer la salud, ni la obligación de asistir a misa los domingos. Muchos laicos pensaban que maldecir y blasfemar sin premeditación de querer ofender a Dios no era pecado, la ira y la costumbre lo excusaban todo, no podían recibir castigo por ello. Los blasfemos justificaban su conducta:

7 CABANTOUS, A., Histoire du blasphème..., p. 72.

8 Ibidem.

9 La documentación judicial refuerza esta explicación. Jesús María Usunáriz indica que los tribunales reales apenas tuvieron relevancia en la persecución de blasfemos. Según los datos aportados, en el Archivo de la Chancilleria de Valladolid existen 19 procesos contra blasfemadores procedentes del País Vasco, de ellos, 17 fueron juzgados entre 1493 y 1523, durante uno de los períodos de mayor conflictividad confesional en la península. En los fondos de Tribunales Reales del Archivo General de Navarra se repite la misma situación, sólo se contabilizan una docena de procedimientos judiciales por idéntico delito concentrados casi todos en los mismos años de agitación religiosa. Cf. USUNÁRIZ, J. M.: «Verbum Maledictionis. La blasfemia y el blasfemo de los siglos XVI y XVII», en GARCíA BOURRELLIER, R. USUNÁRIZ, J. M (eds.)., Aportaciones a la historia social del lenguaje: España, siglos XIV-XVIII), Madrid, 2006, p. 210. 
No tomarás el nombre de Dios en vano. Blasfemia y castigo divino en Cataluña...

«O Pare! Dirá un malehidor de Cristo, aixó de malherí es en mi una costum tan inveterada, que sens advertirho m'escapan las malediccions y per lo tant penso, que Deu no me castigará (...). Pare, si malehesch, es que la ira, o malicia m'ho fa fer, yo a la horas no estich en mi, y no se I que'm dich, y per tant Deu no'm castigará» ${ }^{10}$.

El discurso eclesiástico afirmaba que la muerte y los infortunios graves de la vida eran a menudo expresiones punitivas de la cólera de Dios, causadas por las lenguas blasfemas de malos cristianos que hacía recaer la cruel represalia celestial sobre las naciones o localidades en las que residían, aflicciones extensivas a la misma familia del blasfemo en forma de calamidades incompresibles. El clérigo capuchino catalán Joan de Sant Feliu de Guixols predicaba sobre este asunto a mediados del siglo XVIII en el transcurso del Sermó de las impaciencias y malas paraulas:

«Passa avant provocant la ira de un Deu de queus facia sensibles y las suas venganzas. La mort de aquella filla tua, de aquell cap de bestiar, de ahont creus que ha tingut origen, sino de aquella maledicció ques donares, de aquella imprecació que llansares contra de ella. La desgracia, los infortunios de la casa, tot preve de las tuas malediccions, diu lo profeta Zacarias ${ }^{11}$.

Un predicador dominico del siglo XVIII, de cuyo nombre la historia no ha dejado constancia, advierte a la comunidad de fieles reunida para escuchar el sermón dominical del elevado riesgo de padecer sequías, tempestades de granizo o mortandad de animales que arruinen la producción agrícola, si la gente no corrige su actitud recalcitrante en maldecir el nombre de Dios ante el más mínimo percance:

«Moltes de vostres desgracias son efecte, y castich de vostras malediccions. D'hon pensau que venen las morts, o desgracias en los animals, de la sequedad y las pedregades, que destruyesen les fruits de vostres Camps, viñas, o arbres?. Es molt de temer, que les malediccions, que tiran per totas parts ${ }^{12}$.

La boca que exhala blasfemias infecciona con su maldad, la consecuencia del mal se materializa en la enfermedad. En Las Cántigas de Santa María —compo-

10 «Oh Padre, dirá un maldecidor de Cristo, esto de maldecir es en mi una costumbre tan arraigada, que sin advertirlo me escapan las maldiciones y por tanto pienso, que Dios no me castigará (...). Padre, si maldigo, es que la ira, o malicia me lo hacen hacer, yo entonces no estoy en mi, no sé lo que me digo, y por tanto Dios no me castigará», Biblioteca Universitaria de Barcelona (B.U.B)., «Pláticas sobre el decálogo», Ms. 898, Sin numerar.

11 «Pasa antes provocando la ira de un Dios del que os hacéis sensibles a sus venganzas. La muerte de una de tus hijas, de aquella res, de donde piensas que ha tenido su origen, sino en aquella maldición que pronunciaste contra ella. La desgracia, los infortunios de la casa, todo procede de tus maldiciones, dice el profeta Zacarías», Archivo de los Padres Capuchinos de Cataluña, (A.P.C.C.)., SANT FELIU DE GUIXOLS, J., «Sermó de las impaciencias y las malas paraulas», Pliego suelto, Sin numerar.

12 «Muchas de vuestras desgracias son efecto y castigo de vuestras maldiciones. ¿De donde pensáis que vienen las muertes, o desgracias en los animales, la sequedad y las granizadas, que destruyen los frutos de vuestros campos, viñas, árboles?. Es mucho de temer, que las maldiciones, que tiran por todas partes» «Pláticas sobre el decálogo», Ms.cit, Sin numerar. 
siciones en honor a la Virgen compuestas a mediados del siglo XIII y de cuya autoria se atribuye en todo o en parte al monarca Alfonso X El Sabio- la lepra recibe el nombre de gafidad, representada literariamente por puntos de tonalidad marrón que cubren las partes visibles del cuerpo, y que son el producto del castigo divino que determinados personajes reciben por cometer pecados como el de la lujuria o la blasfemia, imagen literaria que transmite un mensaje simbólico y moralizante $^{13}$. En esta misma línea doctrinal, Eiximenis establece un vínculo directo entre blasfemia y peste, ajustándose en lo relativo a este asunto a la doctrina de San Ambrosio y a ejemplos prestados de las biografías de Carlomagno, Edmundo de Inglaterra y de San Luis de Francia. Esta siniestra vinculación pronto se verá ratificada en el plano práctico. El 14 de julio de 1395 las autoridades municipales de Valencia proclaman un bando donde se relaciona el brote de epidemia de peste bubónica que diezmaba la ciudad con la blasfemia ${ }^{14}$. Idéntica conexión la hallamos en un edicto de 1483 publicado en Gerona durante el episodio de infección pestífera que afectó al territorio vecino del Rosellón (Francia) en aquel año ${ }^{15}$. La aparición de enfermedades hasta entonces desconocidas se consideraba un castigo de Dios. Teólogos y moralistas de fines del siglo XV atribuyeron la súbita propagación de una nueva enfermedad venérea - la sífilis- y la pandemia que asoló poco después Europa a la costumbre irrenunciable de la gente por blasfemar y no refrenar los excesos de la lujuria sexual ${ }^{16}$.

Los pecados de la lengua desencadenaban la cólera celestial, la Iglesia construye toda una argumentación discursiva destinada a persuadir a los cristianos de abandonar sin dilación el vicio de blasfemar. Razonamiento religioso en que se concilian el castigo cristiano con el maleficio pagano, las figuras celestiales con los espectros diabólicos.

\section{PASTORAL RELIGIOSA Y MITOLOGIA CRISTIANA}

De un modo general, la Iglesia consideraba al conjunto del pueblo cristiano como un compuesto de grandes pecadores que se habían alejado de la senda moral trazada por Dios, difíciles de reformar por tener el alma encallecida por el pecado y que tan sólo la aplicación de una pastoral terrorífica podía someter. Hasta el

13 MORENTE PARRA, M.: «La imagen de la lepra en las Cántigas de Santa María de Alfonso X El Sabio", Anales de historia del arte, 34, Madrid, 2007, pp. 24-45.

14 LLOMPART, G.: «Blasfemias y juramentos cristológicos en la Baja Edad Media catalana», Hispania Sacra, XXVI, 1973, p. 7.

15 Ibidem,

16 BOROBIO, M.V.: «El enigma de la sífilis», Boletín Seimc, 2009. La raíz etimológica del vocablo tiene su origen en el pecado de la blasfemia. El nombre de la enfermedad se lo debemos a Girolamo Frascatoro de Verona, autor de un poema épico titulado Syphilis sive morbo gallico y del tratado De contagionibus et contagiosis morbis, publicado en Lyon en 1554. En su composición poética explica como Silfido blasfema del dios Apolo, como castigo el hijo de Zeus envía a la tierra la enfermedad que toma el nombre del blasfemador.Cf. PÉREZ IBAÑEZ, M.J.: «Mitos y textos médicos renacentistas», en NIETO, J.M (ed.).: Estudios de religión y mito en Grecia y Roma (Jornadas de filología de Castilla y León), 1994. 
No tomarás el nombre de Dios en vano. Blasfemia y castigo divino en Cataluña...

siglo XVIII la imagen de la predicación católica ofrecida a los fieles del Creador del Universo era el de un Ser infinitamente bueno, que sin embargo, no dudaba un instante en castigar terriblemente las almas obstinadas en el pecado que rechazasen reconciliarse con él. Las tácticas eclesiásticas para conquistar las voluntades humanas se fundamentaban en reglas de actuación destinadas a impresionar las conciencias, procedimientos que asociaban la culpabilidad, las amenazas y los consuelos, basados en una doble estrategia: la difusión de un discurso de terror y el despliegue alternativo de un mensaje seductor de salvación para los cristianos que quisieran volver al redil de los justos. Un método de enseñanza evangélico heredado de la predicación apocalíptica medieval, basado en la pedagogía de la fuerza de las palabras y de las imágenes. Como señala Jean Delumeau, la pastoral de la muerte está estrechamente ligada a la pastoral de la seducción, pero los fieles, finalmente, estarían mucho más marcados por el contenido espantoso de la primera que no por el mensaje de esperanza de la segunda ${ }^{17}$.

Los blasfemos que perseveran en la contumacía serán arrojados sin misericordia al pozo del infierno. Una de las obras capitales de la literatura medieval europea imagina a los blasfemadores sufriendo espantosos tormentos en las grutas del infierno. Dante Alighieri (1265-1321) coloca en el recinto tercero del círculo séptimo de la casa infernal a quienes cometieron violencia contra Dios y sus designios: blasfemos, homosexuales y usureros. Los blasfemos están tendidos boca arriba, lo que les impide protegerse de la lluvia. Elucubración literaria que traduce fidedignamente el discurso de la cultura docta acerca de las penas que padecerán las almas insumisas a los preceptos de la Iglesia cuando traspasen el umbral de la vida física.

En un parágrafo de un sermón doctrinal correspondiente al tercer domingo de Adviento, predicado en muchas localidades catalanas en el transcurso del siglo XVIII, el oficiante describe la morada infernal, lugar donde únicamente se oyen alaridos blasfemos:

«Haveu de saber Christians, que lo lloch del Infern, es un pou tant profundo, tan dilatat, y tant ample, que tindran dintra de si mes milions de dimonis, y comdennats que estrellas no hi es en lo cel, ni arenas en lo mar; y encara que es tant dilatat, y tant ample, estan alli los miserables condennats estrets, y apretats com las rejoles en un forn; es lo Infern un lloch ab gran manera fosquissim, alli no entran, ni entraran la llum del sol, ni resplandor de la llum, sino que tot es tenebros palpable mes que los de Egypte. Es lo Infern un lloch tancat ab portas de bronze, y sorellots de ferro. Es lo Infern un lloch de gravísima confusió, y desconcert, alli no se hou sino blasfemias, y renechs contra Deu, y de Maria Santísima» ${ }^{18}$.

17 DELUMEAU, J.: Le péché et la peur. La culpabilisation en Occident, XIIle-XVIIle siècles, París, 1983, p. 384.

18 «Habéis de saber cristianos, que el lugar del infierno, es un pozo tan profundo, tan dilatado, y tan ancho, que tendrá dentro de si más millones de demonios, y condenados que estrellas no hay en el cielo, ni arenas en el mar; y aún que es tan dilatado, y tan ancho, están allí los miserables condenados estrechos, y apretados como los ladrillos en un horno; es el infierno un lugar en gran manera oscurísimo, allí no entran, ni entrarán la luz del sol, ni el resplandor de la luz, sino que todo es tenebroso palpable más 
La literatura española del Siglo de Oro habla del infausto destino que aguarda a las almas blasfemas. Pedro Calderón de la Barca (1600-1681) escribe acerca de ello en su comedia El Purgatorio de San Patricio:

\author{
«Aquí en profundas cavernas \\ se quejaban tristemente \\ condenados maldiciendo \\ a sus padres y parientes, \\ tan desesperadas voces \\ de blasfemias insolentes, \\ de reniegos y por vidas \\ repetían muchas veces, \\ que aún los demonios temblaban»19.
}

Los infiernos son representados como cuevas abismales de las que surgen llamaradas de fuego. Los pecadores son arrastrados hacía aquel inmundo lugar por los demonios y consumidas sus almas por llamas incandescentes entre gritos blasfemos de eterna desesperación como lo describe San Ignacio de Loyola en un párrafo de sus Ejercicios espirituales:

«El primer punto será ver con la vista de la imaginación los grandes fuegos, y los ánimos como en cuerpos ígneos. El segundo oír con las orejas llantos, alaridos, blasfemias contra Cristo nuestro Señor, traen a la memoria las ánimas que están en el infierno, unos porque no creyeron el advenimiento; otros, creyendo, no obraron según sus mandamientos» 20 .

La descripción de los abismos infernales y las penas terroríficas a las que estaban sometidas eternamente las almas de los blasfemos es heredada en buena parte de la tradición cristiana antigua basada en los evangelios apócrifos del Apocalipsis. En este marco, el texto apócrifo neotestamentario más antiguo correspondiente a esta categoría es el atribuido falsamente a Pedro Apóstol. El Apocalipsis de Pedro se sitúa entre los años 132 y 135 con el trasfondo histórico de las persecuciones de Simón Bar Kochba contra los judíos ${ }^{21}$. Esta obra tuvo mucha aceptación en la Antigüedad cristiana hasta ser considerado un libro canónico, condición que perdería posteriormente. En el año 1887 se encontró un fragmento en una tumba de Akhmon (Egipto). En uno de los pasajes, Pedro contempla los castigos que sufren los blasfemos en el infierno:

que los de Egipto. Es el infierno un lugar cerrado con puertas de bronce, y aldabas de hierro. Es el infierno un lugar de gravísima confusión, y desconcierto, allí no se oyen sino blasfemias, y reniegos contra Dios, y María Santísima», «Pláticas sobre el decálogo», Ms.cit. Sin numerar.

19 CALDERÓN DE LA BARCA, P.: El purgatorio de San Patricio (Tercera jornada), Biblioteca Virtual Miguel de Cervantes, Alicante, 2006.

20 LOYOLA, I. de.: Ejercicios espirituales, Obras completas, Biblioteca de Autores Cristianos, Madrid, 1963 , p. 214.

${ }_{21}$ Iluminado mesiánico judío que se alzó en armas contra Roma en el año 132 consiguiendo que se uniesen a su causa la mayoría de la población. Una guerra desesperada puso en apuros al ejército imperial romano hasta que el emperador Adriano envió al general Julio Severo para sofocar la rebelión. En 135 cae Jerusalén y los últimos reductos de resistencia son aniquilados. 
No tomarás el nombre de Dios en vano. Blasfemia y castigo divino en Cataluña...

\begin{abstract}
«Más también vi en otro lugar, enfrente de aquel, que era todo tinieblas. Y era el lugar de los castigos. Y los allí castigados y los propios ángeles que los castigaban, estaban vestidos tan tenebrosamente como tenebroso el aire de aquel lugar. $Y$ había allí gentes colgados de la lengua. Eran los blasfemos contra el camino de la justicia. Y bajo ellos ardía un fuego que les atormentaba (...). Y no lejos de ellos se hallaban más mujeres y hombres que se rasgaban los labios con los dientes y recibían hierro ardiente en los ojos, como tormento. Eran aquellos que habían blasfemado y hablaron perversamente contra el camino de la justicia. Y frente a ellos había otros hombres y mujeres más, que con los dientes se rasgaban sus labios y tenían llameante fuego dentro de la boca. Eran los testigos falsos»22.
\end{abstract}

La visión del infierno descrita está en la línea de la concepción judía y cristiana. Todos los pecados castigados en el Apocalipsis de Pedro están condenados en el Antiguo y Nuevo Testamento (blasfemias, adulterios y fornicaciones, asesinatos, avaricia, usura, homosexualidad, idolatría, apostasía, robo).

La literatura religiosa apocalíptica azuzará la imaginación de ciertos religiosos visionarios. Los tormentos infernales están muy descritos en las visiones del jesuita Bernardo de $\operatorname{Hoyos}^{23}$. Poseemos la transcripción de la visión contemplativa del infierno que tuvo lugar el día 9 de enero de 1730 a las diez menos cuarto de la mañana. Es la tercera de las visiones apocalípticas iniciadas en septiembre del año anterior. El religioso explica que en aquella jornada y hora se hallaba en oración cuando súbitamente se encontró en medio de un campo espacioso acompañado de su ángel de la guardia que le hizo de improvisado guía en su visita a la guarida infernal:

«Mi santo Ángel, volviéndose a mi, me dijo: "Veni et ostemdam visionem hanc magnam". Empecé a seguirle, de repente abrió la tierra una boca, por donde entró mi Ângel y yo en su seguimiento, para ver esta gran visión cuando de los desdichados, en quienes ejecuta su furor la omnipotencia de la divina justicia. A pocos pasos vi salir por la misma abertura de la tierra por donde yo había entrado una gran multitud de demonios que, habiendo arrojado en las llamas infernales las muchas almas que habían ganado en la mortandad numerosa de esta epidemia pasada, volvían al mundo a tender sus redes para precipitar en el abismo a los miserables. Y habíamos andado unos veinte pasos, cuando me dijo mi Ángel: "Vide et scribe", y al punto saliendo de aquel callejón por donde había entrado, vi una cueva inmensa de fuego revuelto en humo y que aún la misma luz negaba. Eché los ojos por aquella inmensidad de fuego, pero ni alcanzaba el final ni veía a don-

22 Cf. BLÁZQUEZ MARTÍNEZ, J.M.: «Los castigos del infierno cristiano en el Apocalipsis de Pedro» en DÍEZ DE VELASCO, F (ed.).: Miedo y religión. IV Simposio Internacional de la Sociedad Española de Ciencias de la Religión, Madrid, 2002, pp. 331-332.

${ }^{23}$ Este miembro de la Orden de San Ignacio nace en Torrelobatón (Valladolid) en 1711. A los 17 años toma los votos simples y a los 24 enferma de tifus y fallece, tan sólo algunos meses después de su definitiva ordenación sacerdotal. En su corta vida escribió diversas obras de carácter espiritual, apuntes y sermones que nunca fueron publicados. Conocemos la vida y el contenido de la producción literaria del joven fraile gracias al libro Vida del venerable. y angelical joven P. Bernardo Francisco de Hoyos de la Compañía de Jesús, escrito por el también jesuita Juan de Loyola en 1739, basándose en los escritos que dejó en vida. Los textos originales no se han conservado. Cuando los jesuitas regresaron a España tras la expulsión de 1767, los papeles de Fray Bernardo depositados en el Colegio de San Ignacio de Valladolid habían desaparecido. 
de llegaba su anchura. Bien hube menester aquí me animase la presencia del Ángel, pues sólo esta primera visita bastaba a quitarme la vida. Percibí un hedor intolerable, un ruido espantoso, unos gritos descompasados y unos aullidos como de perros rabiosos, vi que, impelidos de furor y de rabia, saltaban hacia arriba algunos condenados y caían precipitados de los demonios, como una gran piedra a su centro, a la voracidad de las llamas» ${ }^{24}$.

Seguidamente, Bernardo pasa a describir con detalle los diferentes tormentos padecidos por los condenados, según la calidad del pecado principal. En una parte del infierno observó como los demonios se empleaban en castigar a los blasfemos:

«Los que habían pecado con jurar y blasfemar a la bondad de Dios, arrojaban serpientes de sus asquerosas bocas, que se ceñían con ellas y les iban despedazando. Y los demonios les herían en la boca, ya cortándoles la lengua, ya desbaratándoles la dentadura, ya metiéndoles barras de hierro ardiendo, ya embutiéndoles plomo derretido, que les penetraba todos los huesos; ya con otros trazos diabólicos les causaban atrocísimos tormentos y acerbisimos dolores. Horrorizado estaba yo de lo que veía, aturdido de las blasfemias que oía contra Dios y su Santísima Madre (lo cual me causaba tal dolor que era bastante a quitarme la vida, si Dios milagrosamente no me la conservara), atónito con los monstruos que se me mostraban y, fuera de mi de la gritería y alaridos que oía»²5.

Con toda seguridad, Bernardo de Hoyos estaría muy influenciado por la lectura de las obras de Teresa de Jesús, ya que las descripciones ofrecidas del infierno por la santa de Ávila y el jesuita tienen muchos puntos en común: las dos suceden cuando ambos religiosos se encuentran en oración; súbita traslación a un campo abierto; la puerta del infierno es un paso largo y estrecho; olor pestilencial insoportable, etc.

Las visiones del más allá no eran patrimonio exclusivo de religiosos. Los seres celestiales a veces también se comunicaban con los laicos para condenar el pecado de la blasfemia y otras conductas anticristianas. El antropólogo norteamericano William A. Christian, Jr. ha estudiado la lógica de la conducta divina en las apariciones a gente sencilla de la cultura rural en la Castilla y Cataluña de los siglos XIV-XVI26. Su estudio llega a una interesante conclusión: La Virgen María y los santos son mensajeros de Dios, delegados para informar a la colectividad de los riesgos catastróficos que la aguardan si persisten en no renunciar a los pecados que tanto encolerizan al Creador, ofreciendo los medios para evitar los castigos que les tiene reservado en forma de peste o hambres. Según los mensajes transmitidos a los humanos en sus apariciones, los vicios que más desagradan a Dios son las blasfemias y juramentos, mencionado cinco veces, seguido del juego en público, robo y rivalidades de pueblos, con una sola mención ${ }^{27}$. Christian expone al-

24 Idem, p. 67.

25 Ibidem

${ }^{26}$ CHRISTIAN, W.A, Jr.; Apariciones en Castilla y Cataluña (siglos XIV-XVI), Madrid, 1990.

27 Idem, p. 261. 
No tomarás el nombre de Dios en vano. Blasfemia y castigo divino en Cataluña...

gunos casos harto ilustrativos registrados en Cataluña para sostener su argumentación.

Miquel Noguer, un campesino acomodado que vivía en la parroquia de Sant Andreu de El Torn, en el episcopado de Gerona, declara ante las autoridades diocesanas correspondientes haber visto a la Virgen María el día 25 de octubre de 1483 cuando rezaba en una ermita abandonada cercana a la localidad. En su comparecencia testificó que era hombre muy devoto acostumbrado a rezar el Angelus en aquel lugar cuando regresaba al mediodía de cazar. Una mañana que volvía de caza se detuvo frente a la entrada de la capilla y se arrodilló para orar, como habitualmente hacia, ya que no podía entrar en el interior del edificio religioso por permanecer las puertas cerradas con llave. En medio de la oración oyó que alguíen gimoteaba en su interior. Sobresaltado empujó instintivamente la puerta y milagrosamente se abrió. A pocos pasos halló una preciosa niña de siete u ocho años de edad vestida con una tunica blanca que rezaba fervorosamente, suplicando misericordia a Jesucristo. La criatura se dirigió al estupefacto testigo y le dijo en medio de sollozos que era la Virgen María, afligida por la peste que su Hijo enviaría a El Torn y poblaciones vecinas para castigar su infidelidad religiosa. La Virgen-niña le comunica que sólo el arrepentimiento les puede salvar de una muerte segura y si en adelante vuelven a cumplir escrupulosamente con las obligaciones cristianas: pagar los impuestos establecidos a la Iglesia, dar caridad a los pobres, respetar las últimas voluntades testamentarias de los difuntos y ejecutar sus voluntades, observar los domingos y fiestas de precepto, y sobre todo «se vullan separar y guardar de jurar de Deu» ${ }^{28}$. Por último, manda que la ermita vuelva a reabrirse al culto religioso y que cada viernes del año haya procesiones de todas las parroquias circundantes para rendirle homenaje en aquel lugar. Dicho esto, la Virgen desapareció de su vista y las puertas se volvieron a cerrar por si solas cuando hubo traspasado el portal.

Ciento veinticinco años más tarde la Virgen reaparece en una localidad muy cercana a EI Torn. La vidente María Torrent, mujer de condición humilde y esposa de jornalero, declara el 8 de diciembre de 1618 ante las autoridades eclesiásticas haber visto a Nostra Senyora dels Arcs en el municipio de Sant Pau (Gerona) en el día de Todos los Santos de aquel año cuando regresaba a su casa en la parroquia de Sant Aniol procedente de Sant Miquel de Loret, lugar de su nacimiento, triste por no haber cumplido con los responsos a las almas de sus padres, enterrados en el cementerio del lugar. Por no molestar al párroco rector, ocupado en otros asuntos, no quiso importunarle con su demanda incumpliendo así con su obligación. Regresó ya de noche cerrada a su casa apenada por lo sucedido. Por el camino solitario y oscuro le invadió el miedo, encomendándose a la protección de la Virgen del Arcs de la que era devota. Mientras rezaba el Rosario a su protectora se le apareció una mujer hermosa, resplandeciente, vestida de un blanco inmaculado. Presa de pánico, la aparición le infundió calma diciéndole que no tuviese ningún te-

28 Idem, p.182. 
mor, que era la Virgen María comisionada por Dios para instruirla en el proceder cristiano. Entre los preceptos destacaba el no jurar ni blasfemar delante de los niños que cuidada, encargándole que transmitiera a los habitantes de Sant Aniol la gran cólera que experimentaba su Hijo cada vez que se juraba y blasfemaba en su nombre, amenazando con enviar una peste devastadora si el mensaje de su Madre no era atendido ${ }^{29}$.

Sin embargo, y pese a las alarmantes voces de clérigos, eruditos o visionarios, que llamaban a refrenar las lenguas impetuosas de muchos laicos si no querían padecer la misma suerte de los blasfemadores en el infierno, ignorando los avisos contenidos en los mensajes de la Virgen o los santos que prevenían de futuros padecimientos físicos en la tierra si continuaban obstinados en injuriar a Dios, lo cierto era que las blasfemias disfrutaban de gran aceptación popular en la Cataluña del siglo XVIII:

«En aquesta Provincia se tiran las blasfemias mes horrendas. Perque? Que ou per los camins, quant a un carreter se li encalla lo carro, o a un traginer li cau l'animal? ¡Ah Pare! en direu, nos habem de tapar las orellas, per no sentir aquella boca infernal; alli se cuidan los votos, y per vidas, los sagrats, y coronats, y no hi ha sant en lo cel, a qui no provoquian ab mil injurias. ¿Qué sentir per las casas, per las plasas, per los camps, y per las eras? (...). En totas parts ¡Pare! ab dolor de nostras animas sentim paraulas injuriosas a sa Divina Majestad; en una casa oim a un marit impacient, malehir a Deu, y al sant matrimoni per no saber sufrir la pena de sa muller; en altre sentim un pare iracundo que vota a Deu, y a Christo, perque los fills no fan lo que'ils mana; en las plasas y carrers oim gent viciosa, que ab la major insolencia renegan del creador. En los camps y en las eras se vomitan contra el cel las blasfemias mes horrendas. Aquí es queixan ab rabia de Deu, perque el temps no ve com ells volen; alla malaheixen als sants perque han tingun mala collita; en una part insultan a Maria SSma perque nos ha fet guanyar lo plet, que portaban; en altres anomenan ab rabia la sanch, la mort, y passio de Jesu-Christ, perque son infamats, y perseguits de un contrari. Ab una paraula, Pare, ha cundit tant en nostre desgraciat temps aquest infernal modo de parlar, que apar, que la terra s'ha convertir en un infern» ${ }^{30}$.

29 Idem, pp. 190-193.

30 «En esta provincia se tiran las blasfemias más horrendas. ¿Porqué?. ¿Qué se oye por los caminos, cuando a un carretero se le encalla el carro, o a un arriero se le cae el animal? Ah Padre! me diréis, nos hemos de tapar las orejas, para no sentir aquella boca infernal; allí se cuidan los votos, y por vidas, los sagrados, y coronados, y no hay santo en el cielo, a que no provoquen con mil injurias. ¿Qué oís por las casas, por las plazas, por los campos, y por las eras? (...). En todas partes ¡Padre! con dolor de nuestras almas oímos palabras injuriosas a su Divina Magestad, en una casa oímos a un marido impaciente, maldecir a Dios, y al santo matrimonio por no saber sufrir la pena de su mujer, en otra oímos un padre iracundo que vota a Dios, y a Christo, porque los hijos no hacen lo que se les manda; en las plazas y calles oímos gente viciosa, que con la mayor insolencia reniegan del creador. En los campos y en las eras se vomitan contra el cielo las blasfemias más horrendas. Aquí se queja con rabia de Dios, porque el tiempo no va como ellos quieren; allá maldicen a los santos porque han tenido mala cosecha; en una parte insultan a María SSma porque no les ha hecho ganar el pleito, que llevaban; en otros nombran con rabia la sangre, la muerte, y pasión de Jesucristo porque son infamados, y perseguidos de un contrario. En una palabra, ha cundido tanto en nuestro desgraciado tiempo este infernal modo de hablar, que aparte, la tierra se ha convertido en un infierno». BUB, «Pláticas sobre el decálogo». Sin numerar. 
No tomarás el nombre de Dios en vano. Blasfemia y castigo divino en Cataluña...

La Iglesia acude al recurso pedagógico de los exempla como procedimiento eficaz para erradicar de la conducta de los cristianos la fea costumbre de blasfemar. Los predicadores medievales y del Antiguo Régimen se valían de este método didáctico de adoctrinamiento religioso para ilustrar en sus sermones y clases de catecismo situaciones que podían derivar en fuente de peligro para los cristianos ${ }^{31}$. Los sermonarios de los misioneros católicos estaban llenos de exempla moralizantes que ilustraban el comportamiento a seguir para evitar la condena del alma. El tema central de muchos de ellos estaba relacionado con el mundo demoníaco, argumentado en tres ejes principales: el arrepentimiento y el libre arbitrio del pecador frente a una situación extrema que pusiera en peligro su vida, el repudio a Satanás y la reconciliación con Dios. Su discurso principal se apoya en el miedo al infierno y en las fuerzas diabólicas que lo habitan. Estas historias edificantes son presentadas a menudo como hechos reales extraordinarios sucedidos recientemente, situados en lugares y en un tiempo que son familiares a la mayoría de los oyentes de la plática moralizante. Sus protagonistas suelen ser gente sencilla con oficios comunes (campesinos, artesanos, comerciantes modestos...), la nobleza y la burguesía parecen no tener un rol tan destacado. La imprenta contribuirá decisivamente a difundir estas narraciones entre las clases populares más humildes. Las relaciones de contenido más impresionantes son impresas como opúsculos (generalmente no sobrepasaban las dos hojas), denominadas pliegos sueltos o pliegos de corde ${ }^{\beta 2}$, inscritas dentro del género literario conocido como relaciones de sucesos $^{33}$, presentadas frecuentemente bajo forma de versos en romance, muy próximos a la prosa, para que pudieran ser comprendidos en amplios sectores sociales de la población, a menudo acompañadas de viñetas, y con un bajo coste económico para facilitar su compra. Su expansión cultural se propagara gracias a un doble circuito de difusión: la lectura personal y la transmisión oral a través de la memorización transmitida de boca a oreja en las lecturas colectivas ${ }^{34}$. A partir de 1570, empiezan a distribuirse de manera abundante por toda España relatos de mi-

31 Sobre esta temática son esenciales la consulta de las siguientes obras: BREMOND, CL. LE GOFF, J. SCHMITT, J_Cl. : L'exemplum, Lovaina, 1983; BERLIOZ, J. POLO DE BELALIEU, M.A. : Les exempla médiévaux, Carcassonne, 1992 ; VV.AA. : Réthorique et histoire. L'exemplum et le modèle de comportament dans le discours antique et médiéval, Roma, Extrait des Mélanges de l'École Française de Rome, Moyen Âge-Temps Modernes. 92, 1, 1980. Para Cataluña ver: GELABERTÓ VILAGRAN, M.: «Los exempla. Mitología popular, apologética cristiana y cultura impresa en la Cataluña del siglo XVII », Historia 16. Madrid, 1992, pp. 50-58.

32 Sobre el género literario de los pliegos y la literatura de cordel en general sigue siendo imprescindible la lectura de diversas obras clásicas: CARO BAROJA, J.: Ensayo sobre la literatura de cordel, Madrid, 1969; MARCO, J.: Literatura popular en España en los siglos XVIII y XIX, 2 Vols, Madrid, 1977; GARCÍA DE ENTERRIA, M.C.: Sociedad y poesía de cordel en el Barroco, Madrid, 1973; Ibidem.: Literaturas marginales, Madrid, 1983.

${ }^{33}$ Cf. REDONDO, A.: «Les relaciones de sucesos dans l'Espagne du Siècle d'Or, un moyen privilegié de transmission culturelle» en VV.AA.: Les médiations culturelles, París, 1989, pp. 55-67; ETTINGHAUSEN, H.: «The news in Spain: Relaciones de sucesos in the Reigns of Philip III and IV », European History Quartely, 14, 1984, pp. 1-20,

${ }^{34}$ Cf. REDONDO, A. : «Le diable et le monde diabolique dans les relaciones de sucesos (Espagne, $1^{\mathrm{e}}$ moitié du XVIle siècle)«en DUVIOLS, J-P. MOLINIÉ-BERTRAND, A (eds.). : Enfers et damnations dans le monde hispanique et hispano-américaine (Actes du Colloque International), París, 1996, pp. 131158. 
lagros que alcanzarán su apogeo editorial en el siglo XVII. Estas relaciones son un medio ideal para difundir los valores del catolicismo postridentino de la Contrarreforma en su encarnizado combate contra los malos católicos y el protestantismo ${ }^{35}$. La atroz relación busca impresionar al lector u oyente para así favorecer su reflexión interna que le lleve a la renuncia voluntaria del pecado ${ }^{36}$. Las historias narradas en los cuadernos de cordel y en los exempla eclesiásticos son ciertas, advertencias de Dios a los pecadores:

La Iglesia utilizaba esta potente arma literaria para aterrorizar a la gente sobre los peligros de entregarse a las diversiones mundanas que ofendían gravemente a Dios. Las mayores represalias divinas contra los cristianos de moral corrompida y de lengua blasfemadora incontinente tenían su origen en las fiestas carnavalescas. En aquellos días era corriente escuchar en las calles, casas, tabernas y lugares concurridos las blasfemias más horrorosas sin importar quien las oyese. De ello se quejaba un predicador dominico en un sermón contra el Carnaval predicado en Cataluña a principios del siglo XVIII: «No se veuhen sino accions miserables, deshonestas, mil profanitats y paraulas indecents, sens atendrer si las ou, la doncella, la viuda, lo religios y lo eclesiastich, pero sapian tambe que pecan mortalment en aquell temps, como en lo demes temps del any „ ${ }^{37}$. Era un tiempo en que la gente blasfemaba sin pudor, en muchos casos con la complicidad tolerante de las autoridades civiles, en una atmósfera de diversión incontrolada. La juventud daba rienda suelta a su alegría blasfemando descontroladamente: «¿Ques lo que pensan, ques lo que diuen, ques lo que fan los fadrins rondant en la nit per los carrers? Las suas bocas en aqueix temps de tenebras semblan unas bocas de infern. Los renechs, y juraments, los votos, es diuen a cada pas ${ }^{38}$.

Las tropelías a que daban lugar los desbordamientos lúdicos del Carnaval no tenían ninguna justificación para la Iglesia. Los integrantes de las comitivas gro-

35 El catolicismo tradicional rápidamente identifica a Lutero con Satán

${ }^{36}$ La seducción por esta clase de historias no se limitaba al mundo católico. Alexandra Walsham dice que en la Inglaterra protestante de los siglos XVI y XVII existía una amplia circulación literaria de narraciones milagrosas en las que Dios juzga y castiga a los pecadores recalcitrantes. La historiadora británica indica que los reformadores ingleses estaban fascinados por esta literatura donde se narraban los castigos enviados por el cielo a blasfemos, adúlteros, alcoholicos, personas que no guardaban las fiestas de precepto, etc. Los puritanos recopilaron colecciones manuscritas de anécdotas macabras acerca de muertes horribles sucedidas a pecadores obstinados. Algunas de estas compilaciones sirvieron como base para la confección de numerosos catálogos publicados en el transcurso de la Alta Edad Moderna. La autora señala como estos relatos fantásticos acabaron convirtiéndose con el tiempo en una especie de folklore protestante que ayudó a suavizar y contrarrestar los efectos más negativos y destructores del protestantismo. Cf. WALSHAM, A.: «Le théâtre des jugements de Dieu. Le providentialisme et la réforme protestante dans l'Anglaterre des XVle et XVIle siècles» en Histoire, économie et société, 2003, 22, 3, pp. 325-348).

${ }_{37}$ «No se ven sino acciones miserables, deshonestas, mil profanidades y palabras indecentes, sin atender si las oye, la doncella, la viuda, el religioso, el eclesiástico, pero sepan que pecan mortalmente en aquel tiempo, como en los demás tiempos del año», Archivo de la Corona de Aragón, (A.C.A.).: «Sermón contra los excessos», Monacales-Universidad, Leg. 130, Sin numerar.

38 «QQué es lo que piensan, qué es lo que dicen, qué es lo hacen los mozos solteros rondando por la noche por las calles?. Sus bocas en este tiempo de tinieblas parecen unas bocas del infierno. Los reniegos, y juramentos, los votos, se dicen a cada paso». «Pláticas sobre el decálogo», Sin numerar. 
No tomarás el nombre de Dios en vano. Blasfemia y castigo divino en Cataluña...

tescas carnavalescas se exponían a recibir los castigos de la cólera divina en forma de muertes repentinas, posesiones diabólicas, enfermedades y toda clase de desgracias a los que se habían hecho merecedores por su mala conducta. El clero prevenía a los católicos de los graves peligros de participar en las chanzas paródicas y blasfemas del Carnaval con ejemplos espeluznantes, como el ocurrido a un luterano por atreverse a blasfemar en la ciudad francesa de Aviñón durante un bullicio carnavalesco en un año indeterminado del siglo XVII:

«En la ciudad de Aviñón del Papa en el convento de Santa Madalena a los 3 de febrero, que era sábado de carnestolendas, estava el Santísimo Sacramento patente por la devoción que todos los años por tales desaforados días suelen tener ${ }^{39}$, quando toda la tarde passava gran multitud de mascaras gritando, y alarideando delante de la iglesia, porque como allí ay muchos hereges de toda secta, irreverenciavan quanto podían aquel lugar.

Acertase a pasar un corrillo de algunas veynte mascaras por delante de dicha iglesia, que ivan por una parte, y otro corrillo por otra, quando un hereje luterano que iva en un corrillo, empeço a gritar a unas honestas señoras palabras tan suzias que causavan horror a los que estavan dentro de la iglesia, y por ser las vozes tan infames, hazian eco en aquel sagrado concavo, para pedir venganza delante de Dios, y continuando el mal nacido tan lascivas palabras, parecía que no las pronunciava bien con la mascara en la cara, que se la quitó, y hizo muchas fuerças en repetirlas muy alto, y en tanto, y en tanto fue, que los que estavan dentro la iglesia huvieron de cerrar las puertas, por no oyr tan horrorosa pronunciación; y como dicho luterano vio que cerraban las puertas (movido del demonio) quiso arremeter adentro, y como no pudo entrar, cogió una piedra, y dando golpes a las puertas, aún continuaba con la misma suciedad de palabras; y como Dios nuestro Señor aún en esta vida para exemplo de otros quiere castigar a los que tan excesivamente menosprecian su Divina presencia, diole el castigo bien merecido al delito. Quedose en la puerta de la iglesia sin fuerças, y como un desmayo sin poder hablar más, quando muchos de su compañía acudieron a ver lo que tenía, y quando fueron allí, vieron que la lengua le iva creciendo toda negra, y le creció hasta que la arrastró dos palmos por tierra. Lleváronle a su casa, y hasta ahora nunca le ha menguado aquella monstruosidad, sino que quando va por las calles la lleva en brazos por no arrastrarla. Se espera en Dios, que el hereje se convertirá, y que será ocasión para sacar los demás de tanta ceguedad...»40.

Sin necesidad de situarnos fuera de las fronteras políticas de la península, una

39 Se refiere al rezo de las «cuarenta horas», período de reflexión penitencial instituido en el siglo XVI por la orden de los capuchinos. En un principio su fundamento era rezar por la paz en el mundo y más especialmente por el fin de las guerras entre católicos y protestantes, pero posteriormente se aplicó a otras necesidades, como el implorar la redención espiritual ante los agravios causados por el caos de las fiestas del Carnaval. Simultáneamente los clérigos predicaban en las catedrales e iglesias contra los vicios de la perniciosa fiesta. En Cataluña esta devoción fue introducida por el fraile Josep de Rocaberti de Barcelona en 1580. Cf. PALMA DE MALLORCA, A.: «Los capuchinos en Cataluña y el fomento de algunas devociones populares», Analecta Sacra Tarraconensia, XXVIII, 1956, pp. 159-175.

40 Carta Nueva, que contiene uno de los más prodigiosos milagros que ha obrado Dios, para manifestar la Real presencia de su Cuerpo Sacramentado, baxo los accidentes candios, enseñando quanto aborrece las palabras lascivas, y como sabe castigar a los que no le veneran, Barcelona, 1674, Sin numerar. 
relación de sucesos del siglo XVIII escrita en romance explica el caso de un hombre que estuvo durmiendo quince meses seguidos como castigo por blasfemar durante una orgía gastronómica carnavalesca ${ }^{41}$. El 9 de febrero de 1723, noche del martes de Carnaval, Alonso Mançanillo, vecino de la localidad de Guexecillo, en el obispado de Oviedo, participaba con su mujer, Marta Ortega, y unos amigos de la juerga festiva hasta que el aturdimiento causado por el alcohol le afectó el cerebro. Cuando apenas se sostenían todos de pie, sus compañeros decidieron poner fin a la velada y retirarse a las habitaciones, excepto Alonso que bramo una blasfemia desafiadora a Dios con un fatal desenlace para su persona:

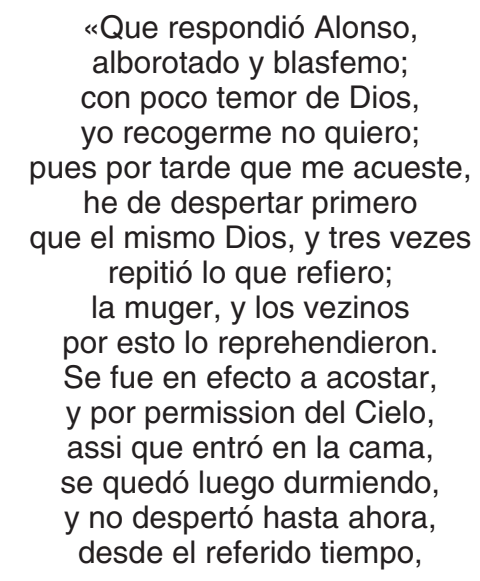

Como el infeliz continuaba sumergido inmóvil en el sueño sin que su esposa y allegados consiguieran devolverle a la realidad, decidieron llevarlo entre todos al santuario de la Virgen de Covadonga. Un sacerdote celebró una misa con el cuerpo yacente del desafortunado Mançanillo. Casi concluido el oficio y cuando el clérigo acababa de impartir la bendición a los fieles, sucedió el milagro esperado:

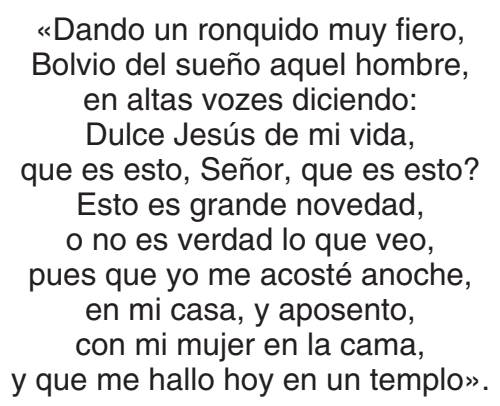

41 Relación, y curioso romance, en que se refiere un assombroso milagro, que obró Dios N.S. por la intercesión de su Amantísima Madre la Virgen de Covadonga, con un hombre devoto suyo el qual estuvo durmiendo 15 meses, en castigo de una blasfemia. Sucedió el dia 1 de mayo de este presente año de 1724. Barcelona, 1724, Sin numerar. 
No tomarás el nombre de Dios en vano. Blasfemia y castigo divino en Cataluña...

Su mujer, parientes y amigos ayudaron a levantarlo y vestirlo. Los admirados sacerdotes le preguntaron que había visto y oído durante el largo período de letargía, a lo que Alonso dio cumplida respuesta:

«Quando anoche me acosté, me dormí luego de presto, y soñé, sin duda alguna, el que yo me avia muerto, y que al tiempo de espirar, el que dos demonios fieros, horribles quanto espantosos, a mi lado se pusieron, y mi cuerpo atormentaban, con grandes hachas de fuego, uno me abrasó la lengua, otro me atravesó el pecho, uno, y otro con frecuencia, me quemaron todo el cuerpo, diziendo: que aquel castigo, merecía por blasfemo, y por ser irreverente, a mi Redemptor eterno, y gastar burlas con él, y pues le perdí el respeto, a mi Dios, y mi Señor, que baxaria al infierno, y diciendo estas razones, rabiosos a mi se asieron, entre tanta confusión, e intolerables tormentos, vi de repente a la Virgen, y a su hijo Juez Supremo, representando justicia, sentado en trono severo, a quien la Virgen Sagrada, suplicó con amor tierno, a su hijo me perdone, mil graves culpas, y yerros,

Dixo JESUS a su madre, muy justos motivos tengo, para condenar a este hombre, porque ha sido tan blasfemo, de mi infinito poder,

se burlaba en todo tiempo, inclinándose a lo malo, Y la Purísima Virgen, con enternecidos ruegos, segunda vez le suplica, que me de todo remedio, Diziendo, Rey Soberano, entre tantos desaciertos, como ha tenido, también, ha sido un humilde siervo, rezándome cada día, una Salve muy atento, y a vuestra Passión Sagrada, también os rezaba un Credo, y por esta buena obra, es justo reciba el premio.

Christo la dixo, Señora, quanto pedís os concedo, y a los demonios les dixo, me dexassen, y lo hizieron, $y$ al recibir este gozo, vine a hallarme en este templo".

El discurso ejemplarizante católico era rico en recursos. Una obra de teatro titulada Moralité des blasphémateurs, publicada en Rouen en 1530, escenifica a cinco jóvenes que blasfeman sin parar por membra dei («por la cabeza de Dios», «por la sangre de Dios», etc.) mientras juegan una partida nocturna de naipes en la ciudad belga de Lovaina durante el Carnaval. La escena ilustra las terribles consecuencias de las blasfemias equiparándolas a una nueva crucifixión de Cristo, recordatorio visual de cómo los blasfemos se verán privados de todo beneficio espiritual ni recibirán ningún auxilio en la hora del juicio final ${ }^{42}$. Exemplum de una extraordinaria fuerza impactante, su empleo se extenderá por el continente europeo tanto en imágenes ilustradas como en transcripciones literarias. En uno de los

42 CHRISTIN, O. : Les yeux pour le croire : les dix ommandements en images, XVe-XVIIle siècles, París, 2003, p. 13. 
exempla de un sermón catequético anteriormente mencionado se incluye una versión en lengua catalana de la narración:

«El desordenat abus de carnestoltes es pecat, y cruel, no sols contra nosaltres, ocasionantnos innumerables mals en lo cos, y en la anima, sino tambe contra Christo Nostre Deu; lo llansa y arrastra per terra, lo carrega de assots, lo corona de espinas, li traspassa las mans, y peus, li desconjunta los osos, li dona mort ignominiosa y cruel, li renova tots los torments de sa santísima passio; pues que no quedi entre nosaltres, vaja fora, desterrenlo del orbe christia, no volem un abus, que es sementera de tants pecats, y que tant enfureix a Christo Nostre Deu (...). En Lovaina se juntaren certs joves disoluts en una casa per entregarse a las dissolucions, y desordres del temps, menjant, y bevent sens templanza, y despres resolgueren passar la nit jugant a cartas, alli no se ohia sino juraments, blasfemias, y paraulas indecents. Pasant al apuntar al dia un home molt cristia per lo carrer, encontra a un home estes sobre la terra, tot llegat, ensangrentat, y cubert de feridas de cap a peus, y advertint, que era viu li pregunta, quil havia tant mal posat. $Y$ respongue que aquells joves, que estavan jugant dins la casa. Entra aquell bon home, y los reprengue perque havian maltractat aquell jove; ells, atonits, respongueren, que a ningu havian ferit, y exint tots al carrer ja no encontraren al home, ab que conegueren que ells ab sos juraments, blasfemias, y altres pecats, havien renovat los torments de JesuChrist» ${ }^{43}$.

El contenido de la predicación no podía ser más inquietante para el público oyente: quienes participasen de algún modo de la festividad profana y se entregaran sin refrenarse a los placeres del juego y del alcohol que encendiesen las bocas con juramentos y blasfemias, martirizaban a Cristo como los verdugos romanos lo hicieron en su crucifixión y estaban condenados de antemano a quemar en las llamas del infierno.

Los exempla escriturados o impresos en Cataluña también recogen casos de imprudentes blasfemos que terminaron pagando caro la osadía de provocar a los santos. Desde la Alta Edad Media los laicos recurrían a los poderes taumatúrgicos de los intermediarios celestiales para recuperar la salud. No obstante, el mismo protector celeste que tantos favores otorgaba causaba la enfermedad, e incluso la

43 «El desordenado abuso del carnaval es pecado, y cruel, no sólo contra nosotros, ocasionándonos innumerables males en el cuerpo, y en el alma, sino también contra Cristo Nuestro Dios; lo lanza y arrastra por tierra, lo carga de azotes, lo corona de espinas, le traspasa las manos y pies, le desconjunta los huesos, le da muerte ignominiosa y cruel, le renueva todos los tormentos de su santísima pasión; pues que no quede entre nosotros, váyase fuera, destiérrenlo del orbe cristiano, no queremos un abuso, que es sementera de tantos pecados, y que tanto enfurece a Cristo Nuestro Dios (...). En Lovaina se juntaron ciertos jóvenes disolutos en una casa para entregarse a las disoluciones, y desordenes del tiempo, comiendo, y bebiendo sin templanza, y después resolvieron pasar la noche jugando a cartas, allí no se oían sino juramentos, blasfemias, y palabras indecentes. Apuntaba el día cuando un hombre muy cristiano pasaba por la calle, encuentra a un hombre tumbado sobre la tierra, lleno de llegas, ensangrentado, y cubierto de heridas de cabeza a pies, y advirtiendo, que era vivo le pregunta, quien le había maltratado de aquel modo. Y respondió que aquellos jóvenes, que estaban jugando dentro de la casa. Entró aquel buen hombre, y los reprendió porque habían maltratado aquel joven; ellos, atónitos, respondieron que no habían herido a nadie, y saliendo todos a la calle ya no encontraron al hombre, con lo que reconocieron que ellos con sus juramentos, blasfemias, y otros pecados, habían renovado los tormentos de Jesucristo». (A.C.A.), «Desordre de Carnestoltes», Monacales-Universidad, Leg. 130, Sin numerar. 
No tomarás el nombre de Dios en vano. Blasfemia y castigo divino en Cataluña...

muerte, si se le desafiaba ${ }^{44}$. La hagiografía cristiana fomenta esta faceta del culto a los santos como instrumento eficaz para la reforma moral de las conductas humanas. La venganza del santo aflige al blasfemo con el mal del que habitualmente cura. San Lupo, obispo de Verona del siglo VI, era invocado como abogado de las enfermedades de la garganta. Un esclavo huido de la casa de su amo se refugió en la iglesia donde reposaban las reliquias corporales del prelado veronés. Atemorizado por la ferocidad de carácter de su dueño y el pavor al inhumano castigo que le esperaba si volvía a la hacienda, se escondió al lado del sepulcro del santo. Descubierto por los criados, su señor clamó enfurecido: ¿Ahí te escondiste?. ¡Ni el mismo Lupo te librará de mis manos!. Inmediatamente después de lanzar la amenaza se le secó la lengua y comenzó a mugir como un buey, muriendo al cabo de tres días por la ofensa inferida al santo ${ }^{45}$.

Algunos exempla rompen parcialmente con la estructura argumental clásica adentrándose claramente en el terreno histórico-político. En uno de los exemplum más antiguos y conocidos de la literatura religiosa medieval europea se explica el mortal castigo que recibió un soldado al agredir la imagen sagrada del niño Jesús en brazos de su madre. La historia se incluye en el Liber Miraculorum del fraile Jean Agnellus escrito entre 1194 y 1200. La narración se enmarca en el fragor del conflicto armado entre las tropas de Enrique II de Francia y Ricardo Corazón de León de Inglaterra con el trasfondo de las rivalidades territoriales que ambos ambicionaban incorporar a sus reinos. El relato de los acontecimientos cuenta que al anochecer del sábado 30 de mayo de 1187 un grupo de hombres y mujeres atemorizados ante la inminente entrada en el burgo de Déols y de su abadía ${ }^{46}$ del ejército ingles, y ante el fundado temor que los invasores prendieran fuego a sus casas y al mismo recinto religioso, se reunieron delante de la puerta norte de la iglesia del monasterio. Ante la imposibilidad de penetrar en su interior por estar las puertas férreamente cerradas, se pusieron todos a llorar demandando protección celestial frente a la estatua de piedra de la Virgen con Jesús infante en los brazos erigida encima del porche. Al poco tiempo, los soldados invadieron la plaza, empezaron a burlarse de la gente allí congregada, uno de los militares tomó una piedra y la lanzó contra la efigie divina blasfemando. Alcanzada por el golpe, un brazo del hijo de María cayó al suelo. Al momento un chorro de sangre fluyó de la piedra mutilada y el soldado sacrílego se derrumbó en tierra fulminado sin vida ${ }^{47}$. La historia no separa política y religión, burgo y reino, culto mariano y protección, profanación de imágenes con el castigo feroz de la blasfemia y la iconoclasia.

${ }^{44}$ Sobre las relaciones entre la Iglesia, los santos y la comunidad de fieles ver LITLLE, J.K.: «La morphologie des malédictions monastiques», Annales, 1, 1979, pp. 43-60; GEARY, P.: «L'humiliation des saints", Annales. 1, 1979, pp. 27-42.

${ }^{45}$ CAMPAMAJOR TORNABALL, A.: «La tradición popular en nuestra especialidad», Boletín de la Societat Catalana d'Otorinolaringologia i Patología cervicofacial, Barcelona, 2006.

46 Centro de Francia.

47 HUBERT, J.: «Le miracle de Déols et la trêve conclue en 1187 entre le roi de France et d'Angleterre», Bibliothèque de l'École de Chartres, 1935, 96, p. 292. 
A veces, la literatura narrativa religiosa se alimenta directamente de la tradición folklórica popular para elaborar un discurso compatible con la doctrina teológica y clerical. La Iglesia manipula las creencias mitológicas más antiguas y arraigadas en las mentalidades colectivas de la sociedad rural europea de los siglos XVI y XVII con el fin de invertir su contenido primitivo y transformarlo en un instrumento de enseñanza religiosa. La cultura folklórica medieval interpretaba el mundo por el intermediario de una serie de aportaciones culturales anteriores que habían forjado internamente una sólida estructura de pensamiento mítico-profano. El peso de la herencia cultural politeísta de la civilización europea anterior al cristianismo no había desaparecido del imaginario colectivo. Como indica Jacques Le Goff, la persistencia de creencias míticas no cristianas en la sociedad medieval, que se prolongara incluso a siglos posteriores, es una característica de la religión vivida por amplios sectores de la población rural del continente sin que ello implique ninguna contradicción:

«Sin embargo, aunque el paso al monoteísmo es sin duda fundamental, no pienso que un monoteísmo puro y duro se pueda instalar sólidamente y durante mucho tiempo en un medio como el del mundo europeo occidental. Los hombres y las mujeres de esas regiones tienen la costumbre de estar rodeados de personajes sobrenaturales, por no decir divinos. Distingamos sobrenatural y divino, pues lo que permitió que un número considerable de tales personajes sobrevivieran en el interior del sistema cristiano, fue precisamente que no eran de naturaleza divina y que, por consiguiente, no hacían sombra al nuevo Dios» ${ }^{48}$.

La cultura popular rural de la Edad Media creía en la existencia de seres fabulosos, habitantes de lugares situados en parajes remotos de tierras incultas donde el asentamiento humano era inexistente, a causa del pavor que inspiraba la presencia allí de imponentes criaturas mitológicas, guardianes feroces de sus territorios. Las montañas y los bosques son los habitáculos preferidos de toda una fauna de genios y espíritus de la naturaleza que el cristianismo, en su progresivo avance evangelizador, recluye en marcos espaciales caracterizados por su difícil accesibilidad y aislamiento geográfico. Son los refugios de todo el bestiario del imaginario folklórico que en el pasado legendario se habían erigido en las indiscutibles figuras fantásticas dominadoras del mundo espiritual pagano y de sus creencias, lugares salvajes vinculados al peligro, tierras incultas, palacios de los genios y de las fuerzas maléficas. Las fuentes bajomedievales registran aún la pervivencia de extrañas bestias míticas recluidas en las altas cimas de montañas y de bosques frondosos e inhóspitos, sitios que la gente evitaba penetrar por miedo a exponerse a la cólera salvaje de sus monstruosos residentes. Gervais de Tilbury ${ }^{49}$ relata como en la cima de la montaña del Canigó, enclavada en los pirineos orientales

48 LE GOFF, J.: El Dios de la Ëdad Media, Madrid, 2005, p. 21

49 Historiador inglés nacido en Essex a mediados del siglo XII, hacia 1212 escribió el libro Otia imperiales, dedicado al emperador Otón IV de Brunswick, en cuyas páginas recoge toda una serie de narraciones legendarias europeas de carácter mítico-folklórico. 
No tomarás el nombre de Dios en vano. Blasfemia y castigo divino en Cataluña...

franceses, en la raya fronteriza con Cataluña, existe un profundo lago en cuyo interior anidan monstruos diabólicos. El humano que se atreve a subir hasta allí e interrumpir su quietud queda expuesto a la venganza furiosa de las extraordinarias fuerzas malignas de sus moradores: "Se encuentra allí, según cuentan, una morada de demonios (...) si se echa al lago una piedra o algo pesado, estalla de inmediato una tormenta, como si los demonios estuvieran enfurecidos»50. Los habitantes de los pueblos situados en las proximidades de la falda de la montaña no se atrevían nunca a subir, ni siquiera a acercarse a las estribaciones de su cima por el temor que los monstruos del lago se despertaran.

El relato no se ajusta para nada a la realidad geográfica ya que el único lago que posee la montaña es el Etang dels Estanyols, asentado en una llanura a 500 metros por debajo de la cima, aunque esto sea lo que menos importe para el contenido folklórico de la narración. En la misma comarca pirenaica franco-catalana del Conflent están ubicados varios lagos misteriosos donde según cuenta la tradición legendaria anidaban seres espeluznantes. Uno de los lugares más temibles para los lugareños era el Etang Noir (Lago negro), situado a 2.505 metros de altitud, bautizado así por la negrura de sus aguas y ser la sede siniestra de monstruos colosales.

La Iglesia cristianiza la vieja creencia folklórica diabolizando las ancestrales criaturas mitológicas que la conquista religiosa cristiana había desterrado en aquellos aislados emplazamientos. Detrás de estos seres mitológicos se hallan ahora los diablos, y el lago es la antecámara del mismo infierno. El dominico Reginald Poch, —catedrático de teología en la Universidad de Perpiñán y uno de los más activos predicadores catalanes de fines del siglo XVI y primer tercio de seiscientos-, publica en 1627 una obra que lleva por título Compendio de la vida, muerte y milagros de los gloriosos labradores San Galderique de Canigó y San Isidro de Madrid, donde se atribuyen las fuertes tormentas que regularmente azotan aquel macizo pirenaico a la obra de algunos ángeles malos expulsados del cielo tras la rebelión de Lucifer que encontraron refugio en aquellas incultas tierras donde permanecen encerrados en los hondos abismos de las aguas de sus lagos. Por este motivo, el clero y los feligreses de las parroquias vecinas tenían la costumbre en cada primavera de acudir en procesión hasta los lagos misteriosos, y una vez allí proceder a bendecir sus aguas para conjurar las formidables energías diabólicas de los seres maléficos allí residentes: «También es posible que tengan allí particular morada y habitación algunos de los que cayeron del Cielo (...), y los curas de las parroquias vecinas acostumbran todos los años, ir a ellos en devota procesión y los bendicen con particulares ceremonias ${ }^{51}$. El lago no solamente es una de las guaridas en la tierra de los demonios que se habían negado a adorar a Dios una vez hubo terminado la creación del mundo, sino también la boca de entrada

50 LECOUTEUX, Cl.: Demonios y genios comarcales en la Edad Media, Barcelona, 1999, p. 160.

$51 \mathrm{POCH}$, R.: Compendio de la vida, muerte y milagros de los dos gloriosos San Galderique de Canigó y San Isidro de Madrid, Perpiñán, 1627, p. 50. 
del mismo infierno donde las almas de los condenados son atormentadas para toda la eternidad. Esta estrategia eclesiástica de despaganizar el lugar, reemplazando las arcaicas figuras mitológicas del mundo profano por demonios pobladores de insondables cavernas infernales, está testificada desde el siglo XV. Jeroni Pau (1458-1497), uno de los más renombrados humanistas catalanes de aquella centuria, escribe sobre ello hacia el año 1475 en su tratado geográfico De fluminibus et montibus hispaniarum libellus:

«Diuen que al seu interior hi ha les estances de les ombres i dels dimonis, i que se senten crits de gent que plora i gemecs terrorifics, i afirmen que aquets llocs penetran fins a les regions infernals i que els sembrants $i$ els arbres regats amb la malignitat de la seva aigua es cremen i s'assequen ${ }^{52}$.

Los mismos ángeles caídos que desafiaron al Creador en los orígenes del cosmos planetario son los encargados de castigar eternamente las conductas disolutas de las almas humanas que se hubieran hecho merecedoras de residir en tan horrendo sitio. Esteban de Corbera, historiador fallecido en 1633, autor de CathaIuña illustrada, obra publicada en 1678, vasta descripción de la economía, geografía y la historia del Principado, recoge la tradición cristiana de la leyenda: «También escriven que a vezes se oyen dentro del estanque bramidos, y llantos, vozes dolorosas, y gemidos, y que el agua hierve a borbollones, y quema la tierra adonde llega»53. Los hijos de padres blasfemos eran serios candidatos a ser engullidos en las entrañas de las aguas del infernal lago por las fieras diabólicas que vagaban en sus profundidades. Jeroni Pau y posteriormente Jeroni Pujades en 1609 transcriben en catalán un exemplum histórico-legendario inserto en la obra Reductorium morale de Pedro Berchor ${ }^{54}$, —versión de una fuente narrativa más antigua de principios del siglo XIII correspondiente a la obra Otia imperiales de Gervais de Tilbury ${ }^{55}$ - donde se dice que los niños y adolescentes de progenitores blasfemos son raptados por los demonios de aquella caverna acuática para que les sirvieran como esclavos de por vida. Dios permite emerger de las simas subterráneas a los diablos de la montaña para que secuestren de las casas a los hijos

52 «Dicen que en su interior están las estancias de las sombras y de los demonios, y que se oyen gritos de gente que llora y gemidos terroríficos, y afirman que en aquellos lugares penetran hasta las regiones infernales y que los sembrados y los árboles regados con la malignidad de su agua se queman y secan». Cf. PAU, J.: «De fluminibus et montibus hispaniarum libellus» en VILALLONGA, M (ed.).: Obras, Barcelona, 1986, pp. 207-257.

${ }^{53}$ CORBERA, E. de.: Cathaluña illustrada, contiene su descripción en común, y particular en las poblaciones, dominios, y sucesos desde el principio del mundo hasta que por el valor de su nobleza fue libre de la oposición sarracena, Nápoles, 1678, p. 57.

54 Nombre castellanizado de Pierre Bersuire (mencionado también como Bercheure, Berchoire o Bercasis). Religioso benedictino francés nacido en Saint-Pierre de Chemin, cerca de Poitiers, en 1290 y fallecido en 1362. Prior de varios establecimientos religiosos de su orden, cayó en desgracia en 1331 cuando fue encarcelado por hereje. Salvó la vida gracias a la protección del rey Juan II. Su obra literaria más importante es el Reductorium morale, compuesta de treinta y cuatro libros, publicada en Estrasburgo en 1474.

55 DENJEAN, Cl.: «Gens des villes ou peuples des montagnes?. Regards sur les Pyrénées (XIle-XVe siècle», Montagnes Médiévales. Actes de la Société des historiens médiévistes de l'enseignement supérieur public, 34, Chambery, 2003, p. 300. 
No tomarás el nombre de Dios en vano. Blasfemia y castigo divino en Cataluña...

de padres blasfemadores y se los lleven a su guarida. Injuriar a Dios y clamar al diablo para que se llevase a un hijo díscolo era una invitación directa para recibir visitantes indeseables:

«Un pagés de una vila de aquella veynat, ques diu Merchero, y ell se anomena Pere de Mesa (o de taula, que tot es una cosa) tenia una filla petita, la qual sovint lo incitava a yra, y colera, y ell yrat la donava, o encomanava als dimonis. Y perço ells aceptant la comanda, anarem a sa casa, y arrebatant la minyona, ab grans trons y remos se lamportaren. Pasats set anys, un passatger, que passant al peu de la montanya, veu a un home, que amb gran pressa corria, y ab veu plorosa cridara dient: Ay de mi, qui de tant gran pes estich carregat, y appres. Interrogat qui era, respongue, hauria ya set anys passats, estava en la montanya de Canigó, sota commendacio, y mando dels dimonis, usant dell cada dia, de carro per carretejar. Dient que en lo mateix estat era la filla del dit Pere, ajustat, que si son para las sercas per aquella montanya, los dimonis, pera que li tornessin la filla, y subitament, ab un repentino vufar, ysque la minyona, ab la estatura corba seca, y de color de terra, ab los ulls alterats, de horrible, y espantis aspecto, y poch apres estigue reforçada. No molt temps, apres, aquell altre, de los dimonis se servian de carro, ab consemblant conjur, fet tambe per son pare fou deslliurat. $Y$ perço que, como fou arrebatar, era de mes edad, y discrecio, mes fael, y expressament referili coses, que entre si los dimonis feyan en aquell lloc, afirmant que baix del llach o estany, havia un palau molt gran, ahont los dimonis se ajuntaren, y denunciaven a sos majors, lo que per lo mon avian fet ${ }^{56}$.

Esta versión del exemplum recogida de una fuente medieval en los albores del siglo XIII conserva muchos elementos míticos de cultura pagana pre-cristiana. Para liberar a los hijos de las garras de los demonios, los padres no recurren a las oraciones religiosas, sino a los conjuros mágicos. Los carceleros diabólicos no se encuentran sumergidos en las cavidades de la tierra, están a pleno día en la superficie de la montaña atormentando a sus rehenes terrestres con duros trabajos físicos, los cautivos no son conducidos a las cárceles del mundo subterráneo, permanecen al aire libre trabajando para sus amos del ultramundo. El infierno no es un lugar inundado de llamas sino un soberbio palacio ubicado en lo más hondo del

56 «Un payés de una villa de aquel vecindario, que se llama Merchero, y él se nombra Pere de Mesa (o de mesa, que todo es una misma cosa) tenia una hija pequeña, la cual frecuentemente lo incitaba a la ira, y cólera, y él airado la daba, o encomendaba a los demonios. Y por esto aceptan la invitación, fueron a su casa, y arrebatando la muchacha, con grandes truenos y remos se la llevaron. Transcurridos siete años, un viajero, que pasaba al pie de la montaña, vio a un hombre corriendo muy deprisa, y que con voz llorosa gritaba: Ay de mí, que de tan gran peso estoy cargado. Interrogado sobre quien era, respondió, que haría ya siete años, estaba en la montaña del Canigó, bajo custodia, y mando de los demonios, usando de su persona cada día, de carro para carretear. Diciendo que en el mismo estado se encontraba la hija del llamado Pere, que hizo cercos por aquella montaña, para que los demonios le devolviesen la hija, y súbitamente, con un repentino soplar, salio la muchacha, con la estatura encorvada y seca, y de color de tierra, con los ojos alterados, de horrible, y espantoso aspecto, y poco después estuvo reforzada. No mucho tiempo después, aquel otro, del que los demonios se servían como carro, con parecido conjuro, hecho también por su padre, fue liberado. Y como fue arrebatado con más edad, y discreción, le reveló ciertas cosas, que entre si hacían los demonios en aquel lugar, afirmando que debajo del lago o estanque, había un palacio muy grande, donde los demonios se juntaban, y denunciaban a sus mayores,, lo que por el mundo habían hecho». Cf. PUJADES, J. : Coronica Universal del Principat de CAtalunya. Vol.I, Barcelona, 1609, p. 4. 
lago. La lectura de la narración hace imposible sustraerse al recuerdo de una sociedad feudalizada. Los demonios adquieren características de señores feudales habitantes de un inexpugnable castillo subterráneo, transformados en figuras feudalizadas de los seres sobrenaturales primitivos de la mitología indo-europea, y sus prisioneros asemejan a siervos adscritos a la tierra de la que los primeros son propietarios absolutos ${ }^{57}$.

El exemplum recupera la tradición hagiográfica de la figura del diablo secuestrador de niños, uno de los temas preferidos de la hagiografía patrística cristiana de los primeros siglos de la Edad Media. Magí Massó, carmelita catalán del siglo XVII, explica en un exemplum el caso referido por San Gregorio de un padre corrompido que en lugar de enseñar la doctrina cristiana a su hijo de cinco años, lo aleccionaba en el vicio de maldecir y blasfemar. Un día en que el padre sostenía la criatura en sus brazos, blasfemando progenitor e hijo como era en ellos habitual, aparecieron repentinamente unos demonios que lo arrancaron de las manos, gritando el infeliz niño al verse atrapado por las garras de aquellas bestias infernales: «O padre aquí ay unos negros que me quieren tomar, diciendo esto, un demonio tomó al hijo de los brazos de su padre, y en cuerpo, y alma se lo llevó al infierno» ${ }^{58}$.

Del siglo XIII al XV, numerosos exempla reviven la temática del niño inocente raptado por los demonios a causa de la moral corrompida de unos perversos padres, salvado in extremis por la intercesión de la Virgen ${ }^{59}$. Grandes santos fueron víctimas de este rapto diabólico. Desde el siglo XI se creía que San Lorenzo fue secuestrado por un diablo mientras dormía junto a su nodriza; liberado por la Virgen María es abandonado en un bosque y encontrado por un abad en la puerta de entrada de su monasterio frente a un ciervo arrodillado que le rinde adoración. Otra fuente indica que San Lorenzo tuvo un destino análogo pero con un desenlace distinto, fue descubierto entre las ramas de un laurel (de ahí procede la etimología del nombre) por el Papa Sixto II. San Bartolomé también fue víctima de los raptores diabólicos.

En un exemplum en lengua castellana del siglo XVII aparece otra vez el esquema argumental: demonios secuestradores-lugar geográfico mítico-padres blasfemadores-hijos torturados; aplicado nuevamente a la misteriosa montaña pirenaica del Canigó:

«Una madre impaciente moradora de algún lugar vezino del monte, que se llama Batea hechó la maldición cierto día a una muchacha hija suya, y la maldición

57 Según Claude Lecouteux, el genio de la montaña adopta esencialmente tres formas: la de animal monstruoso, la de gigante, y la del caballero de vida depravada y malas costumbres. El primero suele habitar en una gruta o lugar subterráneo, los otros dos en castillos o fortalezas. En el caso que nos atañe, el exemplum es una síntesis de ambos. Cf. Claude Lecouteux, Demonios y genios... p. 160.

${ }^{58}$ MASSÓ; M.: Arbol fructuoso, Barcelona, 1677, p. 98.

59 GAIFFIER, B. de. TERVARENT, G. de. : «Le diable, voleur d'enfants. À propos de la naissance des saints Étienne, Laurent et Barthélemy», Analecta Sacra Tarraconensia, XII, 1936, pp. 33-47. Ver tambien SCHMITT, J-Cl.: La herejía del santo lebrel. Guinefor, curandero de niños desde el siglo XIII, Barcelona, 1984, pp. 132-140. 
No tomarás el nombre de Dios en vano. Blasfemia y castigo divino en Cataluña...

\begin{abstract}
fue decirle los diablos te lleven y pudo tanto la maldición de la madre que delante de sus ojos se la arrebataron los demonios sin saber ella adonde la llevaban y no apareció hasta de allí a ocho días que la vio venir flaca, macilente, desgrañada, el cuerpo todo acardenado que causaba grima y horror con su vista, la qual contó punto por punto quanto en aquellos ocho días le avia sucedido diziendo, que la avian llevado a uno de los estanques del Canigó donde avia muchísimos diablos que tenían por oficio el atormentar corporalmente a los hijos que sus padres maldecían porque escarmentasen los demás y que avia visto allí muchos señalando pieça, que fue el hijo de un vezino suyo el qual faltava tantos días avia en la casa de sus padres que se lo avian también llevado por averle hechado sus padres la maldición, assi que por particular disposición del cielo u orden del Señor le conservavan allí vivos algún tiempo padeciendo crueles tormentos y después volvían a casa de los padres desarrapados y mal parados qual ella estava, y que por las entrañas de Christo refrenasen la boca los padres en esta materia de maldecir los hijos porque las maldiciones dellos es poderosa aunque los hijos no tengan culpa, por esto abran el ojo hijo y padre, los hijos por no darle ocasión y los padres en sufrir, que tan presto abran dicho el Spirito Santo te guie, como el diablo te lleve, y crean que en esta materia suele haver grandes castigos $» 60$.
\end{abstract}

El espíritu de la Contrarreforma ha modificado radicalmente la versión medieval. Se han suprimido los contenidos que pudieran recordar cualquier huella de pasado mítico; los padres no recurren a la magia para neutralizar los encantamientos diabólicos, todo queda en manos de la providencia divina; los demonios ya no poseen rasgos de nobles feudales, son espíritus malignos dedicados exclusivamente a mortificar los cuerpos de los jóvenes; el cautiverio de los retenidos no implica trabajo físico para beneficio de las fuerzas del mal, sufren sólo severos maltratos corporales como castigo por las maldiciones pronunciadas por sus padres; los diablos no viven en suntuosas residencias palaciegas, sino en lóbregas cuevas de fuego. Un cuadro perfecto que sintetiza las esencias de la moral cristiana contrarreformista de pánico al diablo, aborrecimiento de la costumbre de maldecir y blasfemar de los hijos, advertencia contundente a los padres que no se corrigen, confianza en la magnanimidad divina. En todos los casos, las maldiciones de los padres contra sus descendientes naturales son una invitación potencial para que los demonios tomen posesión de los cuerpos de los hijos.

El mito pagano de la procesión nocturna de las almas condenadas a errar perpetuamente sobre la tierra conducidas por un ente del imaginario mitológico, sirve de escenario argumental para mostrar los trágicos peligros a los que puede verse abocado el blasfemo. El conductor de este cortejo fabuloso remite a Hallequin, personaje legendario que domina todo el folklore medieval y moderno europeo. Figura mitológica perteneciente al antiguo fondo cultural indoeuropeo, adquiere diversas denominaciones semánticas en función de las diferentes culturas en que se manifestase. En los textos se nos aparece, indistintamente, como jefe de un ejército salvaje de jinetes, o, guía de una comitiva fantástica de espíritus errantes que no encuentran tranquilidad en ninguna parte. La tradición dice que los suicidas, las

$60 \mathrm{POCH}, \mathrm{R}$ : Compendio de la vida, muerte y milagros... 
personas fallecidas de muerte violenta no absueltas del pecado mortal y los recién nacidos muertos sin recibir el sacramento del bautismo, integraban la siniestra caravana fantasmal. En el transcurso de los siglos XI y XII la Iglesia intenta cristianizar esta creencia. Para justificar su discurso, el clero argumentaba que las historias de estas fantasmagóricas apariciones aludían al purgatorio itinerante de las almas que no hallaban reposo ni en el cielo ni en la tierra ${ }^{61}$. A finales del siglo XII, cuando la Iglesia encuentra un lugar específico donde situar el purgatorio, esta interpretación no tiene ya razón de ser. La tropa mítica es entonces diabolizada. El caudillo que conduce la horda nocturna es presentado como un fantasma demoníaco, e incluso, asimilado al propio Lucifer. El encuentro fortuito con este cortejo venido del otro mundo podía tener funestas consecuencias.

Esto le sucedió a Joseph Gener, un campesino natural de la localidad de Olesa de Montserrat, en el camino de regreso a Barcelona, lugar de su residencia, tras visitar a sus parientes en la casa familiar ${ }^{62}$. En la noche del 3 de febrero de 1679 volvía a la ciudad a través de senderos solitarios de montaña en noche cerrada cuando sin darse cuenta se halló perdido en la espesura del bosque. Asustado, empezó a correr por los vericuetos montañosos sin rumbo fijo con la esperanza de encontrar la buena senda, cuando la mala fortuna hizo que cayera de bruces en una profunda hondonada del terreno, sufriendo heridas en la piel y múltiples magulladuras. Desbordado por la cólera comenzó a blasfemar a gritos. En este mismo instante tuvo un encuentro imprevisto con la horda fantástica. La versión catalana de la narración describe el carácter militar de este siniestro ejército: «Li aparegue veurer un bulto de home agigantat ab una escopeta, o massa de armas en las mans...y ab tot lo dit acompanyament dels dits cavalls, com si fos un exercit de caballería» («Le pareció ver un bulto de hombre agigantado con una escopeta, o maza de armas en las manos...y con acompañamiento de caballos, como si fuese un ejército de caballería» $)^{63}$. La figura de Hallequin, rey del cortejo de las almas en pena que no encuentran reposo, es descrita como un caballero de estatura gigante de aspecto humano con un una gran escopeta o maza en las manos, descripción literaria exacta transcrita en las narraciones apologéticas medievales de historias extraordinarias.

La tradición folklórica del mito es adaptada a los términos de la ortodoxia cristiana. Extraviado en la inmensidad del bosque, sin nadie que le socorriera, llevado por el pánico y la ira, blasfema de manera furiosa e, inmediatamente, como castigo a su pecado, aparece la espantosa manifestación de ultramundo. El hombre es

${ }^{61}$ LE GOFF, J. : La naissance du purgatoire, París, 1981

62 Triunfo glorioso...humildemente le invocan e imploran, a donde el dicho Joseph Gener en hecho propio, a mayor gloria de Dios, alabanza de su Santísima Madre y aumento de la devoción del rosario, y assí mismo, corrección y escarmiento de los coléricos, denuncia lo que a él le aconteció, Barcelona, 1679

63 Jerónimo Taix, Llibre del miracles de Nostra Senyora, Barcelona, 1686. El autor del texto es un fraile dominico del convento de Santa Caterina de Barcelona nacido en 1503. La obra aparece por vez primera en 1540 y a lo largo de los siglos XVI y XVII conocerá diversas reediciones. El relato es muy probablemente una actualización de un exemplum medieval, insertado en el marco espacial y cronológico vivido por la gente que lo escuchaba. 
No tomarás el nombre de Dios en vano. Blasfemia y castigo divino en Cataluña...

transportado en cuerpo y alma al centro del infierno donde se encuentra cara a cara frente al mismo monarca de los demonios y de toda su corte satánica, en compañía de las almas condenadas a vagar junto a las huestes infernales hasta el final de los tiempos, representadas por una multitud de misteriosas luces prisioneras de las caballeros fantasmas. Inmovilizado por el terror de la horripilante visión, se acordó entonces que era cofrade de la Virgen del Rosario, fervientemente implora su auxilio entre sollozos de arrepentimiento y enseguida es restituido al mundo de los vivos.

La intercesión de la Madre de Dios en las situaciones críticas de la vida es uno de los temas clave de la literatura de los exempla, y uno de los principales procedimientos empleados por la propaganda doctrinal religiosa del barroco. Las categorías morales que propone la narración son claras: la remisión del pecado y los castigos del infierno no se alcanzan más que por la vía de la contrición de la conciencia y la ayuda salvadora de la Virgen María y de los santos. El blasfemador obstinado y que recae continuamente en este censurable vicio debe renunciar a toda esperanza de obtener la conmiseración divina. Su sentencia de muerte espiritual está firmada de antemano, la paciencia de Dios está colmada y lo único que le espera cuando abandone la envoltura carnal una vez terminada la vida física terrestre son los crujidos de las llamas del infierno.

\section{CONCLUSIONES}

Para las autoridades religiosas el blasfemo es una de las figuras emblemáticas responsables del desorden moral que imperaba en la tierra y un peligro cierto para la seguridad de las poblaciones por el riesgo de que Dios descargara sobre la colectividad entera su cólera punitiva sin hacer ningún tipo de distinciones. Inquietud que se incrementaba todavía más en las coyunturas de crisis a causa de acontecimientos extraordinarios como devastadoras pestes, catástrofes meteorológicas o conflictos bélicos.

El combate contra las blasfemias se enmarca dentro de un amplio proyecto de sacralización de la sociedad emprendido por la Contrarreforma católica. El proceso de moralización social iniciado por las autoridades religiosas postridentinas tiene como uno de sus objetivos extirpar de los hábitos corrientes de las familias el vicio de blasfemar. La Iglesia enseñará a los laicos a controlar los desbordamientos emocionales causados por la cólera a los que conducían los infortunios diarios de la vida, expresados a menudo mediante reniegos y juramentos blasfematorios. A fin de neutralizar cualquier beligerancia divina y brindar su protección espiritual a las personas, la Iglesia elabora un discurso adoctrinador cuya lectura no ofrece muchas veces una separación nítida entre sacro y profano, político y religioso.

La estrategia básica para erradicar las conductas blasfemas descansará sobre procedimientos terroristas de amedrantamiento religioso fundamentados en la 
ecuación pecados públicos=desgracias físicas o sociales. Las narraciones terroríficas de visionarios y los discursos contenidos en los exempla de reforma moral son dos instrumentos perfectos canalizadores de esta política aculturizadora. Estratagemas culturales que desvelan la lógica de una sensibilidad religiosa popular imbuida de creencias folklórico-míticas antiguas, extrañas al cristianismo, y de las que la religión institucional será plenamente partícipe. 